\title{
Aplikasi Zebrafish (Danio rerio) pada Beberapa Model Penyakit Eksperimental
}

\author{
Ari Yuniarto ${ }^{1,2}$, Elin Yulinah Sukandar ${ }^{1}$, Irda Fidrianny³ ${ }^{3}$ dan I Ketut Adnyana ${ }^{1}$ \\ ${ }^{1}$ Kelompok Keilmuan Farmakologi dan Farmasi Klinik, Sekolah Farmasi, Institut Teknologi Bandung (ITB) \\ ${ }^{2}$ Rumpun Bidang Ilmu Farmakologi, Sekolah Tinggi Farmasi Bandung \\ ${ }^{3}$ Kelompok Keilmuan Biologi Farmasi, Sekolah Farmasi, Institut Teknologi Bandung (ITB)
}

Korespondensi: Ari Yuniarto

Email: ariyuniarto@yahoo.co.id

\begin{abstract}
ABSTRAK: Zebrafish (Danio rerio) merupakan jenis ikan tropis berukuran kecil yang banyak ditemukan di negara India dan Asia Selatan. Hingga saat ini, zebrafish telah digunakan sebagai organisme model untuk pengembangan berbagai model penyakit, studi toksikologi, studi neurobiologi, gangguan-gangguan metabolisme, dan pengembangan genetika. Beberapa keunggulan dari penggunaan zebrafish antara lain mekanisme adaptasi terhadap lingkungan, naluri yang cukup bervariasi, pola sirkadian, dan berbagai macam mekanisme adaptasi lainnya. Secara genetika, zebrafish juga memiliki persamaan gen yang menyerupai manusia. Persamaan gen ini merupakan proses evolusi yang terjadi selama ratusan juta tahun yang lalu. Sebagai tambahan, zebrafish juga memiliki persamaan-persamaan lainnya dengan manusia antara lain yaitu pada sistem saluran pencernaan, jaringan adiposa viseral, sistem otot rangka, dan sistem organ lainnya. Persamaan gen, sistem saluran pencernaan, jaringan adiposa viseral, sistem otot rangka, dan sistem organ lainnya menjadikan landasan utama untuk pengembangan dan eksplorasi berbagai macam model penyakit pada manusia. Beberapa model yang dapat diaplikasikan pada model zebrafish antara lain model obesitas, diabetes mellitus, gangguan jantung atau kardiovaskular, gangguan ginjal, gangguan lipid, penyakit perlemakan hati, dan beberapa model lainnya.
\end{abstract}

Kata kunci: aplikasi; zebrafish; model; penyakit; eksperimental

\begin{abstract}
Zebrafish (Danio rerio) is a type of small size tropical fish which found in India and South Asia. Nowadays, zebrafish have been used as model organism to develop several disease models, toxicology, neurobiology study, metabolic disorders, and genetic development. Some advantages of zebrafish involve adaptation mechanism against environment, various instincts, circadian rhythm, and several types of adaptation mechanism. Genetically, zebrafish has genome similarity to the human. Genome similarity is an evolution process for hundred million years ago. In addition, zebrafish has other similarities with human involve gastrointestinal tract system, visceral adipose tissue, musculoskeletal system, and others organ system. Genome similarity, gastrointestinal tract system, visceral adipose tissue, musculoskeletal system, and other organs become basic principle to develop and explore various types of human diseases. Various model which could be conducted on zebrafish including obesity model, diabetes mellitus, heart or cardiovascular disorders, kidney disorders, lipid disorders, fatty liver disease, and other models.
\end{abstract}

Keywords: application; zebrafish; model; disease; experimental 


\section{Pendahuluan}

Zebrafish (Danio rerio) merupakan jenis ikan tropis berukuran kecil yang dapat ditemukan di sungai-sungai di negara India dan Asia Selatan [1]. Beberapa tahun terakhir, penggunaan ikan zebrafish sebagai organisme model untuk pengembangan genetik, toksikologi, gangguan metabolisme, serta gangguan tubuh manusia lainnya menjadi sangat populer. Zebrafish atau dikenal dengan nama ilmiah Danio rerio memiliki kurang lebih 45 spesies di dunia. Ikan ini merupakan famili Cyprinidae. Garis-garis sebagai corak yang ada pada tubuh ikan terdiri dari beberapa tipe sel pigmen. Garis berwarna biru hitam terdiri dari dua sel pigmen, yaitu melanofor dan iridiofor, sedangkan pada garis berwarna kuning perak terdiri dari sel pigmen xantofor dan iridiofor. Garis-garis pada ikan berfungsi untuk adaptasi terhadap lingkungannya melalui mekanisme kamuflase [2].

Zebrafish (Gambar 1) juga memiliki kemampuan dan naluri yang cukup bervariasi yaitu bisa merasakan sensasi rasa, sentuhan, keseimbangan, dan pendengaran [3]; pola sirkadian yang menyerupai mamalia yaitu aktivitas yang dilakukan pada siang hari dan istirahat pada saat malam hari [4]; serta penurunan kecepatan makan, dan peningkatan agresi pada kondisi tertentu [5].

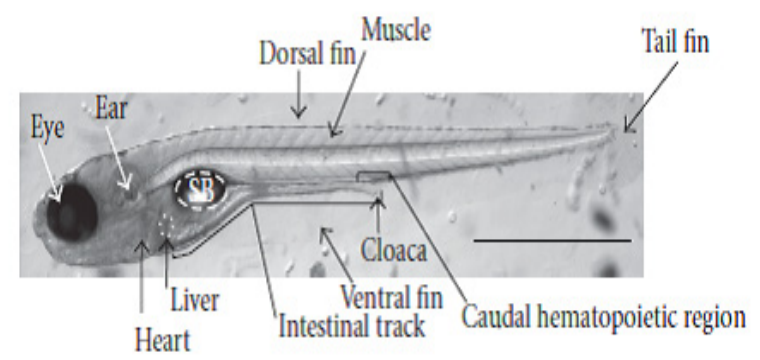

Gambar 1. Struktur anatomi zebrafish (Danio rerio) (Gambar diambil dari Goldsmith dan Jobin, 2012)

Keuntungan dari penggunaan zebrafish adalah proses pembiakan yang cepat, serta satu induk ikan zebrafish dapat menghasilkan hingga ratusan keturunan [6]. Keuntungan lainnya dalam penggunaan zebrafish dibandingkan model organisme lainnya ialah adanya kesamaan gen yang menyerupai manusia atau mamalia. Gen dari zebrafish dan Teleost lainnya, menunjukkan sebuah evolusi yang terjadi selama ratusan juta tahun yang lalu dari mamalia [7]. Pemahaman terhadap genom zebrafish dan genom manusia sangat membantu dalam mengidentifikasi mutasi yang terjadi dan membantu memudahkan dalam mengidentifikasi gen-gen yang terlibat dalam menyebabkan suatu penyakit yang terjadi pada manusia. Disamping kesamaan pada gen, persamaan lainnya antara lain yaitu pada sistem saluran pencernaan, jaringan adiposa viseral, dan sistem otot rangka [8]. Kesamaan gen, sistem saluran pencernaan, jaringan adiposa, sistem otot rangka antara zebrafish dan manusia menjadi landasan dasar untuk pengembangan berbagai macam model penyakit pada manusia [9].

Pada review ini akan didiskusikan tentang aplikasi zebrafish secara eksperimental pada beberapa model penyakit yang meliputi obesitas, diabetes, gangguan kardiovaskular, gangguan ginjal, perlemakan hati, dan beberapa penyakit lainnya. Tujuan dan harapan dari review ini ialah dapat meningkatkan pemahaman terhadap aplikasi zebrafish pada beberapa model penyakit eksperimental dan dapat memanfaatkan informasi yang didapat untuk pengembangan target terapetik atau pengobatan di masa depan.

\section{Aplikasi zebrafish secara eksperimental 2.1. Zebrafish untuk model obesitas}

Obesitas terjadi karena ketidakseimbangan antara asupan energi dan pengeluaran energi [10]. Sistem keseimbangan yang terjadi melibatkan fungsi dari hipotalamus. Sebagaimana pada manusia, zebrafish juga memiliki reseptor leptin dan sistem melanokortin yang terlokasi pada hipotalamus [11-12]. Pemberian Neuropeptide Y (NPY), ghrelin, dan Agouti-Gene Related Peptide (AgRP) pada zebrafish dapat menstimulasi efek makan, sedangkan pemberian CocaineAmphetamine Regulated Transcript (CART) dan Melanokortin dapat menghambat keinginan untuk makan [13]. 
Pada manusia, adanya mutasi gen monogenik atau single-gene pada system reseptor melanokortin-4 (MC4R) dapat menyebabkan obesitas. Sedangkan pada zebrafish, adanya overekspresi AgRP yang memiliki peran sebagai inverse agonis endogen MC4R akan menghasilkan efek peningkatan pertumbuhan pada ikan yang linier dan hipertrofi jaringan adiposa [14]. Untuk mendapatkan modelobesitas padazebrafish dapat dilakukan beberapa pendekatan yang seringkali memang digunakan untuk mendapatkan model obesitas pada hewan pengerat, salah satunya ialah dengan menggunakan induksi makanan tinggi lemak selama periode waktu tertentu [1516].

\subsection{Zebrafish untuk model diabetes mellitus}

Diabetes mellitus merupakan sekelompok penyakit metabolik kronik yang muncul karena tidak cukupnya jumlah insulin atau kerusakan pada sel-sel penghasil insulin didalam pankreas. Saat ini, Zebrafish telah digunakan secara terus menerus untuk studi perkembangan organ pankreas. Pankreas pada Zebrafish memiliki fungsi endokrin dan eksokrin yang terhubung dengan sistem duktal sampai sistem digestif sebagaimana yang ada pada mamalia. Sel islet pankreas Zebrafish terdiri dari sel beta (untuk menghasilkan insulin), sel alfa (untuk menghasilkan glukagon), sel delta (untuk menghasilkan somatostatin, dan sel penghasil ghrelin [17-18]. Zebrafish merupakan model yang sangat baik bila dibandingkan dengan model hewan pengerat untuk memahami kondisi dan patologi dari vertebrata [19].

Hal ini dapat dijelaskan dan didukung melalui beberapa penelitian terhadap zebrafish yang diinduksi oleh beberapa metode. Pemberian streptozotocin dengan dosis tertentu pada zebrafish mampu menyebabkan kerusakan pada sel beta-langerhans pankreas ikan dan memunculkan beberapa komplikasi diabetes yaitu adanya peningkatan pada kadar gula puasa, peningkatan glikasi protein serum, kerusakan pada retina, dan penurunan pada level insulin
[20]. Studi lain menunjukkan bahwa zebrafish yang diinduksi dengan model obesitas mampu memunculkan kondisi hipertrigliseridemia dan diabetes. Mekanisme ini dapat terjadi karena jalur patofisiologi yang terjadi pada zebrafish menyerupai dengan mamalia [21].

\subsection{Zebrafish untuk model gangguan jantung}

Jantung embrio zebrafish secara struktur menyerupai struktur jantung embrio manusia yang tersusun atas atrium dan ventrikel [22]. Zebrafish tidak tergantung pada sistem sirkulasi untuk bertahan di tahap awal perkembangan kehidupan. Oleh karena itu, gangguan pada perkembangan jantung pada embrio tidak menghasilkan efek kematian yang segera. Beberapa model penyakit jantung dapat diterapkan pada model zebrafish mutan [23]. Pada jenis mutan Pandora, jantung tidak memiliki katub, sedangkan pada jenis mutan Jeckyll tidak memiliki ventrikel [24]. Jenis mutan lainnya, yaitu Gridlock juga dapat diterapkan model gangguan koarktasi aorta seperti halnya yang terjadi pada manusia [25]. Beberapa studi menunjukkan bahwa adanya kerusakan pada genetik zebrafish dapat menyebabkan menyebabkan malfungsi sistem kardiovaskular [26].

\subsection{Zebrafish untuk model gangguan ginjal}

Zebrafish juga sangat sesuai pada aplikasi model gangguan ginjal yang meliputi penyakit ginjal polisistik, model gagal ginjal akut, model nefrolitiasis, dan beberapa model lainnya [27]. Pada model penyakit ginjal polisistik, beberapa studi menjelaskan bahwa bagian yang disebut sebagai silia memiliki peranan penting terhadap terjadinya penyakit ini. Beberapa model yang dapat diterapkan pada zebrafish yang erat kaitannya dengan kerusakan pada silia antara lain Bardet Biedl Syndrome, Nephronophthisis, Oro-Facial-Digital, dan Sindroma Meckels.

\subsection{Zebrafish untuk model dislipidemia}

Metabolisme lipid dan lipoprotein pada zebrafish menyerupai dengan apa yang ada 
pada manusia. Pada zebrafish memiliki cukup banyak reseptor nuclear, transporter untuk lipid, apolipoprotein, dan beberapa enzim yang termasuk didalamnya memiliki peran dalam metabolisme lipoprotein [28-29]. Pemberian makanan pada zebrafish dengan makanan tinggi kolesterol, tanpa adanya intervensi genetik, dapat memberikan hasil yang cukup signifikan dalam membentuk model hiperkolesterolemia. Gangguan metabolisme lipid yang terjadi pada ikan dapat memberikan hasil berupa disregulasi pada fisiologis ikan dan berperan penting pada patogenesis inflamasi jaringan adiposa viseral, resistensi insulin, diabetes mellitus, steatohepatitis, gangguan ginjal, beberapa gangguan neurodegeneratif [30] dan kondisi atherosclerosis [31].

\subsection{Zebrafish untuk model perlemakan hati}

Adanya akumulasi lipid yang berlebihan di dalam liver memberikan dampak yang cukup berarti terhadap munculnya beberapa kondisi seperti inflamasi, fibrosis, dan berkembangnya kanker [32-33]. Kondisi ini disebut sebagai nonalcoholic fatty liver disease (NAFLD). Hingga saat ini, kondisi NAFLD berkaitan erat dengan obesitas dan resistensi insulin. Pada model zebrafish, formasi primordium liver, diferensiasi hepatosit, dan cholangiocytes dapat diamati pada waktu 48 jam setelah fertilisasi [34]. Model zebrafish yang dapat diaplikasikan untuk model NAFLD yaitu dengan menggunakan model zebrafish mutant fgr dan zebrafish transgenik [35-36]. Induksi NAFLD pada zebrafish dapat dilakukan melalui beberapa metode seperti penggunaan Tamoxifen dan memberikan makanan tinggi lemak [8, 37].

Sejumlah zebrafish mutan yang mengalami steatohepatitis telah banyakdilakukan identifikasi [38]. Sebagian besar yang terjadi ialah melibatkan gen-gen yang mempengaruhi fungsi biokimiawi liver yang pada tahap lanjut dapat menyebabkan mekanisme stress oksidatif pada liver [39-40]. Penelitian yang menarik ialah dilakukannya mutasi pada s-adenosylhomocysteine hydrolase (ahcy). Ahcy merupakan enzim pemetabolisme yang bertanggung jawab sebagai donor metil yang digunakan untuk sejumlah besar proses biologis. Pada ikan zebrafish mutan yang telah dirusak enzim ahcy-nya, menunjukkan suatu kondisi steatohepatitis dan degenerasi pada organ liver [41]. Kondisi ini juga terjadi pada manusia yang mengalami gangguan genetik langka yaitu defisiensi ahcy menunjukkan suatu kondisi disfungsi liver, gangguan pada fungsi otak yang mempengaruhi perkembangan psikomotor yang meliputi hipotonia, masalah pada makan, serta gangguan pada pernafasan yang berujung pada kematian [42-43]. Oleh karena itu, pada model zebrafish mutan dapat digunakan sebagai model untuk studi patofisiologi pada beberapa kondisi yang serius, salah satunya ialah steatohepatitis dan degenerasi liver

\subsection{Zebrafish untuk model gangguan pencernaan}

Sistem saluran pencernaan yang ada pada zebrafish menyerupai dengan vertebrata tingkat tinggi dengan susunan yang terdiri dari liver, kandung kemih, pankreas, lapisan usus yang memiliki fungsi sekretori dan absorptif [44]. Lapisan epitel yang ada pada usus zebrafish memiliki beberapa tipe sel penting [45]. Pada zebrafish bagian usus anterior yang disebut sebagai intestine bulb, merupakan lumen yang lebih besar dibandingkan pada bagian posterior. Intestine bulb memiliki fungsi sebagai reservoir.

Bagian penting lainnya dari zebrafish adalah pada bagian lambung. zebrafish memiliki organ lambung yang menyerupai vertebrata, sedangkan Teleost lainnya tidak memiliki organ lambung [46]. Defek genetik atau gangguan pada sistem lambung zebrafish dapat memunculkan beberapa kondisi penyakit [47]. Salah satu model gangguan adalah model kanker lambung yang diinduksi Helicobacter pylori. Helicobacter pylori merupakan bakteri gram positif patogen dengan kolonisasi lebih dari $50 \%$ di seluruh dunia. Dampak dari kolonisasi $H$. pylori ini berkaitan erat dengan sejumlah penyakit lambung seperti gastritis, penyakit tukak lambung, dan 


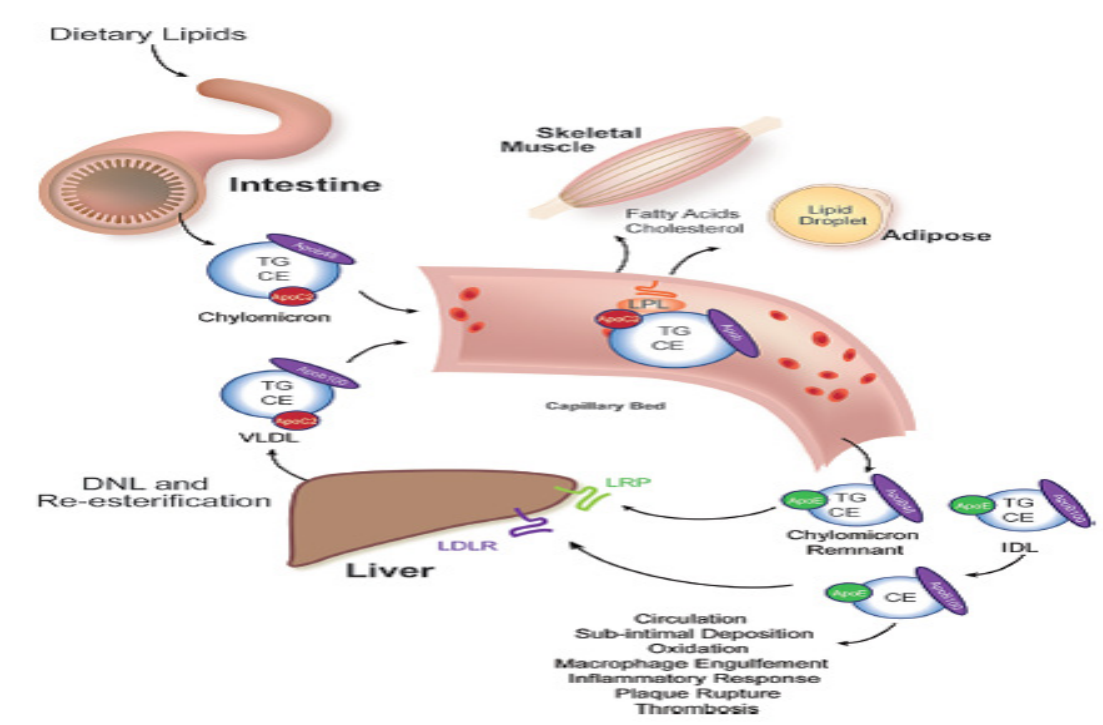

Gambar 2. Proses sintesis ß-lipoprotein di usus dan hati serta modifikasinya pada pembuluh darah (Gambar diambil dari Schlegel A, 2016)

Tabel 1. Manipulasi genetik dan karakteristik model dari zebrafish

\begin{tabular}{llll}
\hline Model Penyakit & Manipulasi genetik & Karakteristik model & Referensi \\
\hline & Mutasi pada trappc111 & $\begin{array}{l}\text { Mempengaruhi stress pada } \\
\text { retikulum endoplasma (RE) }\end{array}$ & [35] \\
Model non-alcoholic fatty & Mutasi pada cdipt & $\begin{array}{l}\text { Mengganggu proses sintesis } \\
\text { phosphatidylinositol } \\
\text { liverdisease (NAFLD) }\end{array}$ & [40] \\
& Mutasi pada ahcy & $\begin{array}{l}\text { Melalui mekanisme pe- } \\
\text { ningkatan lipogenesis de } \\
\text { novo }\end{array}$ & [41] \\
& & & \\
\hline
\end{tabular}

adenokarsinoma lambung [48-51]. Dalam hal ini model yang sesuai untuk infeksi H. pylori dalam korelasinya terhadap gangguan lambung yaitu zebrafish transgenik. Model lain yang sesuai untuk zebrafish adalah inflamasi pada saluran pencernaan [52], model gangguan motilitas [53], model kanker atau tumorigenesis pencernaan [54], penyembuhan luka pada intestinal [55], dan inflammatory bowel disease [56-57].

\subsection{Zebrafish untuk model gangguan sistem syaraf pusat}

Secara anatomi dan struktural dari sistem syaraf pusat zebrafish menyerupai pada manusia. Model gangguan yang dapat diterapkan pada zebrafish untuk sistem syaraf pusat antara lain alzheimer, kecemasan (anxiety), depresi, autisme, schizophrenia, parkinson, penyakit huntington, dan beberapa gangguan lainnya [58-61]. Dalam hal ini, untuk mengembangkan model gangguan sistem syaraf pusat pada zebrafish sangatlah memungkinkan, relevan, dan sesuai untuk dieksplorasi lebih lanjut [62], hal ini karena tidak hanya diperkuat dari struktural anatomi saja, akan tetapi diperkuat dengan jalur transduksi sinyal dan sistem organisasi neuron otak yang cukup baik [63].

Sebagai tambahan, dalam sistem syaraf pusat zebrafish juga tersusun atas neurotransmitterneurotransmitter yang meliputi kolinergik, dopaminergik, dan noradrenergik yang telah terpetakan pada beberapa studi [64-65], adanya blood brain barrier [66], dan Para-glycoprotein (Pgp) yang terdeteksi pada endothelium 
pembuluh darah sistem syaraf pusat.

\subsection{Zebrafish untuk model sistem imunitas}

Zebrafish memiliki sistem imunitas alami yang menyerupai pada manusia yang terdiri dari natural killer cells, makrofag, monosit, neutrofil, dan sejumlah elemen molekuler seluler lainnya yang mulai berfungsi pada 2 hari setelah fertilisasi, sedangkan sistem imunitas adaptif mulai berfungsi pada 4 sampai 6 minggu setelah fertilisasi. Sistem-sistem tersebut sangat relevan terhadap aplikasi zebrafish untuk model sistem imunitas ataupun model gangguannya [67-70].

\subsection{Zebrafish untuk model kanker}

Aplikasi zebrafish untuk model kanker telah dilakukan pada beberapa studi [71-75] dan model zebrafish merupakan modelyang ideal untukstudi tumor atau kanker malignan. Beberapa agen yang diberikan untuk menginduksi kanker antara lain MNNG (N-methyl-N-Nitro-N-Nitrosoguanidine), DMBA (7,12-dimethylbenz(a)anthracene), dan DENA (diethylnitrosamine).

Model-model kanker yang dapat diterapkan antara lain melanoma, leukemia, kanker yang menyerang sistem endokrin, dan beberapa tipe kanker lainnya. Penggunaan xenotransplantasi sel tumor manusia ke dalam embrio zebrafish (xenograft) untuk mengetahui adanya metastasis, migrasi sel tumor, dan angiogenesis juga telah dipelajari lebih lanjut pada beberapa studi [7681].

\subsection{Zebrafish untuk model penyakit genetika}

Beberapa hal yang dapat dijadikan pertimbangan untuk penggunaan zebrafish dalam bidang genetika ialah transparensi, produktivitas, dan kemudahannya dalam pencitraan (imaging). Pendekatan secara genetik dapat dilakukan untuk mendapatkan fenotip zebrafish yang baru dan identifikasi gen-gen baru yang menarik sebagai kandidat yang potensial untuk mencari relevansinya terhadap fenotip yang bertanggung jawab terhadap penyakit-penyakit pada manusia [82-86]. Beberapa penyakit genetika yang dapat diaplikasikan pada model zebrafish antara lain dilated cardiomyopathy, penyakit ginjal polisistik, duchenne muscular dystrophy, dan gangguan kongenital glikosilasi [87-91].

\subsection{Zebrafish untuk model hemofilia}

Model hemofilia dapat diaplikasikan pada zebrafish melalui pemberian zat tembaga. Mekanisme pengukuran dapat dilakukan dengan mengamati fungsi pembekuan darah. Fungsi pembekuan darah dapat diamati secara cepat baik pada model larva ataupun zebrafish dewasa [92-93].

\subsection{Zebrafish untuk model osteoporosis}

Pemberian glukokortikoid dalam jangka waktu yang lama dapat memberikan efek pengeroposan tulang dan me mberikan resiko peningkatan terhadap fraktur tulang pada manusia. Hal inilah yang menyebabkan keterbatasan penggunaan dari glukokortikoid. Model glukokortikoid untuk menginduksi osteoporosis juga dapat diaplikasikan pada embrio zebrafish [94] dan telah dilakukan oleh Barret et al. [95] untuk mendemonstrasikan sebuah persamaan mekanisme yang terjadi antara zebrafish dan manusia.

\section{Kesimpulan}

Penelitian yang dilakukan selama beberapa dekade dengan menggunakan zebrafish sebagai model eksperimental penyakit, studi genetika, studi toksikologi, dan gangguan lainnya memberikan hasil yang cukup menjanjikan. Kesimpulan dari review jurnal ini ialah penggunaan zebrafish pada akhirnya akan memberikan kontribusi yang penting untuk proses identifikasi, karakterisasi gen, studi perkembangan penyakit, fungsi organ, dan perilaku karena beberapa persamaannya yang menyerupai manusia atau mamalia.

\section{Daftar Pustaka}

1. Eaton RC dan Farley RD. Spawning cycle and egg 
production of zebrafish (Brachydanio rerio) in the laboratory. Copeia. 1974;1:195-204.

2. Schilling TF. The morphology of larval and adult zebrafish in Nusslein -Volhard and Dahm (2002) zebrafish-a practical approach. UK: Oxford University Press; 2002.

3. Moorman SJ. Development of sensory systems in zebrafish (Danio rerio). Institute for Laboratory Animal Research Journal. 2001;42(4):292-8.

4. Zhdanova I. Zebrafish: high throughput approach to sleep research. International Conference on Methods and Techniques in Behavioural Research, Wageningen, the Netherlands; 2005.

5. Spence R, Gerlach G, Lawrence C, Smith C. the behavior and ecology of the zebrafish, Danio rerio. Biological Reviews. 2008;83(1):13-34.

6. Kar B dan Subbiah S. Zebrafish: an in vivo model for the study of human diseases. International Journal of Genetics and Genomics. 2013;1(1):6-11.

7. Becker TS dan Rinkwitz S. Zebrafish as a genomics model for human neurological and polygenic disorders. Developmental Neurobiology. 2012;72(3):415-28.

8. Oka T, Nishimura Y, Zang L, Hirano M, Shimada Y, Wang Z, Umemoto M, Kuroyanagi J, Nishimura $\mathrm{N}$, Tanaka T. Diet induced-obesity in zebrafish shares common pathophysiological pathways with mammalian obesity. BMC Physiology. 2010;10(21):1-13.

9. Seth A, Stemple DL, Barroso I. The emerging use of zebrafish to model metabolic disease. Disease Models and Mechanisms. 2013;6(5):1080-8.

10. Han LK, Zheng YN, Yoshikawa M, Okuda H, Kimura Y. Anti-obesity effects of chikusetsusaponins isolated from Panax japonicus rhizomes. BMC Complementary and Alternative Medicine. 2005;5(9):1-10.

11. Zhang C, Forlano PM, Cone RD. AgRP and POMC neurons are hypophysiothropic and coordinately regulate multiple endocrine axes in a larval teleost. Cell Metab. 2012;15(2):256-64.

12. Liu Q, Chen Y, Copeland D, Ball H, Duff RJ, Rockich B, Londraville RL. Expression of leptin receptor gene in developing and adult zebrafish. Gen. Com. Endocrinol. 2010;166(2):346-55.
13. Kawauchi H. Functions of melanin-concentrating hormone in fish. J. Exp. Zool. Part A: Ecological Genetics and Physiology. 2006;305(9):751-60.

14. Song Y dan Cone RD. Creation of a genetic model of obesity in a teleost. FASEB J. 2007;21(9):2042-9.

15. Meguro S, Hasumura T, Hase T. Body fat accumulation in zebrafish is induced by a diet rich in fat and reduced by supplementation with green tea extract. PLOS One. 2015;10(3):1-12.

16. Forn-Cuni G, Varela M, Fernandez-Rodriguez CM, Figueras A, Novoa B. Liver immune responses to inflammatory stimuli in a diet-induced obesity model of zebrafish. Journal of Endocrinology. 2015;224(2):159-70.

17. Shin E, Hong BN, Kang TH. An optimal establishment of an acute hyperglycemia model. African Journal of Pharmacy and Pharmacology. 2012;6(42):2922-8.

18. Capiotti KM, Junior RA, Kist LW, Bogo MR, Bonan CD, Da Silva RS. Persistent impaired glucose metabolism in a zebrafish hyperglycemia model. Comparative Biochemistry and Physiology, Part B: Biochemistry and Molecular Biology. 2014;171: 58-65.

19. Maddison LA, Chen W. Nutrient excess stimulates ß-cell neogenesis in zebrafish. Diabetes. 2012;61(10):2517-24.

20. Olsen AS, Sarras Jr MP, Intine RV. Limb regeneration is impaired in an adult zebrafish model of diabetes mellitus. Wound Repair Regen. 2010;18(5):53242.

21. Gleeson M, Connaughton V, Ameson LS. Induction of hyperglycemia in zebrafish (Danio rerio) leads to morphological changes in the retina. Acta Diabetol. 2007;4(3):157-63.

22. Warren KS, Fishman MC. Physiological genomics: mutant screens in zebrafish. Am. J. Physiol. 1998;275(1):1-7.

23. Fishman MC, Stainier DY, Breitbart RE, Westerfield M. Zebrafish: genetic and embryological methods in a transparent vertebrae embryo. Methods Cell Biol. 1997;52:67-82.

24. Horne-badovinac S, Lin D, Waldron S, Schwarz M, Mbamalu G, Pawson T, Jan Y, Stainier DY, Abdelilah Seyfried S. Positional cloning of heart and soul 
reveals multiple roles for PKClambda in zebrafish organogenesis. Curr. Biol. 2001;11(19):1492-502.

25. Towbin JA, McQuinn TC. Gridlock: a model for coarctation of the aorta? Nat. Med. 1995;1(11):1141-2.

26. Rottbauer W, Just S, Wessels G, Trano N, Most P, Katus HA,Fishman MC. VEGF-PLCy1 pathways control cardiac contractility in the embryonic heart. Genes Dev. 19:1624.

27. Swanhart LM, Cosentino CC, Diep CQ, Davidson AJ, de Caestecker M, Hukriede N. Zebrafish kidney development: basic science to translational research. Birth Defects Res. C. Embryo Today. 2011;93(2):141-56.

28. Babin PJ, Thisse C, Durliat M, Andre M, Akimenko MA, Thisse B. Both apolipoprotein E and A-I genes are present in a nonmammalian vertebratae and are higly expressed during embryonic development. Proceeding of National Academy Sciences. 1997;94(16):8622-7.

29. Avraham-Davidi I, Ely Y, Pham VN, Castranova D, Grunspan M, Malkinson G, et al. Apo $\mathrm{B}$-containining lipoproteins regulate angiogenesis by modulating expression of VEGF receptor- 1 . Nat. Med. 2012;18(6):967-73.

30. Fang L, Liu C, Miller TI. Zebrafish models of dyslipidemia: relevance to atheroschelorosis and angiogenesis. Transl. Res. 2015;163(2):99-108.

31. Schlegel A. Zebrafish models for dyslipidemia and atheroschlerosis research. Front. Endocrinol. 2016;7:1-8.

32. Duan XY, Zhang L, Fan JG, Qiao L. NAFLD leads to liver cancer: do we have sufficient evidence? Cancer Letters. 2014;345(2):230-4.

33. Yu J, Shen J, Sun TT, Zhang X, Wong N. Obesity, insulin resistance, NASH, and hepatocellular carcinoma. In Seminars in Cancer Biology. 2013;23(6):483-91.

34. Chu J dan Sadler KC. New school in liver development: lessons from zebrafish. Hepatology. 2009;50(5):1656-63.

35. Sadler KC, Amsterdam A, Soroka C, Boyer C, Hopkins N. A genetic screen in zebrafish identifies the mutants vps18, nf2, and foie gras as models of liver disease. Development. 2005;132(15):3561-
72.

36. Shieh YS, Chang YS, Hong JR, Chen LJ, Jou LK, Hsu CC, Her GM. Increase of hepatic fat accumulation by liver specific expression of hepatitis $B$ virus $\mathrm{x}$ protein in zebrafish. Biochimica et Biophysica Acta (BBA)-Molecular and Cell Biology of Lipids. 2010;1801(7):721-30.

37. Anezaki Y, Ohshima S, Ishii H, Kinoshita N, Dohmen T, Kataoka E, Sato W, Iizuka M, Goto T, Sasaki J, et al. Sex difference in the liver of hepatocytespecific pten-deficient mice: a model of nonalcoholic steatohepatitis. Hepatology Research. 2009;39(6):609-18.

38. Schlegel A. Studying-non alcoholic fatty liver disease with zebrafish: a confluence of optics, genetics, and physiology. Cell. Mol. Life. Sci. 2012;69(23):3953-61.

39. Cinaroglu A, Gao C, Imrie D, Sadler KC. Activating transcription factor 6 plays protective and pathological roles in steatosis due to endoplasmic reticulum stress in zebrafish. Hepatology. 2011;54(2):495-508.

40. Thakur PC, Stuckenholz C, Rivera MR, Davison JM, Yao JK, Amsterdam A, Sadler KC, Bahary N. Lack of de novo phosphatidylinositol synthesis leads to endoplasmic reticulum stress and hepatic steatosis in cdipt-deficient zebrafish. Hepatology. 2011;54(2):452-462.

41. Matthews RP, Lorent $\mathrm{K}$, Manoral-Moblas $\mathrm{R}$, Huan Y, Gong W, Murray IV, Blair IA, Pack M. TNFalpha-dependent hepatic steatosis and liver degeneration caused by mutation of zebrafish s-adenosylhomocysteine hydrolase. Development. 2009;136(5):865-75.

42. Baric I, Fumic K, Glen B, Cuk M, Schulze A, Finkeistein JD, James SJ, Mejaski-BosnjakV, Pazanin L, Pogribny IP, et al. S-adenosylhomocysteine hydrolase deficiency in a human: a genetic disorder of methionine metabolism. Proc. Natl. Acad. Sci. USA. 2004;101(12):4234-9.

43. Grubbs R, Vugrek O, Deisch J, Wagner C, Stabler S, Allen R, Barić I, Rados M, Mudd SH. S-adenosylhomocysteine hydrolase deficiency: twosiblings with fetal hydrops and fatal outcomes. J. Inherit. Metab. Dis. 2010;33(6):705-13. 
44. Maddula K dan Julura A. Zebrafish in biomedical and drug discovery. Research and Reviews: Journal of Pharmacology and Toxicology Studies. 2016;4(3):134-42

45. Pack M, Solnica-Krezel L, Malicki J, Neuhauss SCF, Schier AF, Stemple DL, Driever W, Fishman MC. Mutations affecting development of zebrafish digestive organs. Development. 1996;123(1):3218.

46. Kwek J, De Iongh R, Nicholas K, Familari M. Molecular insights into evolution of the vertebrate gut: focus on stomach and parietal cells in the marsupial, Macropus eugenii. J. Exp. Zool. Part B, Mol. Dev. Evol. 2009;312(6):613-24.

47. Goessling W dan Sadler KC.Zebrafish: an important tool for liver disease research. Gastroenterology. 2015;149(6):1361-77.

48. Neal JT, Peterson TS, Kent ML, Guillemin K. H. pylori virulence factor CagA increases intestinal cell proliferation by Wnt pathway activation in a transgenic zebrafish model. Disease Models and Mechanisms. 2013;6(3):802-10.

49. Amieva MR dan El-omar EM. Host-bacterial interactions in Helicobacter pylori infection. Gastroenterology. 2008;134(1):306-23.

50. Peek RM Jr dan Blasér MJ. Helicobacter pylori and gastrointestinal tract adenocarcinomas. Nat. Rev. Cancer. 2002;2(1):28-37.

51. Asghar RJ dan Parsonnet J. Helicobacter pylori and risk for gastric adenocarcinoma. In Semin. Gastrointest. Dis. 2001;12(3):203-8.

52. Brugman S. The Zebrafish as a model to study intestinal inflammation. Developmental and Comparative Immunology. 2016;64:82-92.

53. Rich A. A new high-content model system for studies of gastrointestinal transit: the zebrafish. Neurogastroenterol. Motil. 2009;2(3):225-8.

54. Faro A, Boj SF, Clevers H. Fishing for intestinal cancer models: unraveling gastrointestinal homeostatis and tumorigenesis in zebrafish. Zebrafish. 2009;6(4):361-74.

55. Goldsmith JR, Cocchiaro JL, Rawls JF, Jobin C. Glafenine-induced intestinal injury in zebrafish is ameliorated by $\mu$-opioid signaling via enhancement of Atf6-dependent cellular stress responses. Disease Models and Mechanisms. 2013;6(1):146-59.

56. Fleming A, Jankowski J, Goldsmith P. In vivo analysis of gut function and diseases changes in zebrafish larvae model of inflammatory bowel disease: a feasibility study. Inflammatory Bowel Diseases. 2010;16(7):1162-72.

57. Oehlers SH, Flores MV, Okuda KS, Hall CJ, Crosier KE, Crosier PS. A chemical enterocolitis model in zebrafish larvae that is dependent on microbiota and responsive to pharmacological agents. Developmental Dynamics. 2011;240(1):288-98.

58. Best JT dan Alderton WK. Zebrafish: an in vivo model for the study of neurological diseases. Neuropsychiatric Disease and Treatment. 2008;4(3):567-76.

59. Zhdanova IV, Wang SY, Leclair OU, et al. Melatonin promotes sleep-like state in zebrafish. Brain. Res. 2001;903(1):263-8.

60. Cahill GM. Clock mechanisms in zebrafish. Cell Tissue Res. 2002;309(1):27-34.

61. Lee J dan Freeman JL. Zebrafish as a model for developmental neurotoxicity assessment: the application of the zebrafish in defining the effects of arsening, methylmercury, or lead on early neurodevelopmental. Toxics. 2014;2(3):464-95.

62. Grundwal DJ dan Eisen JS. Headwaters of the zebrafish-emergence of a new model vertebratae. Nat. Rev. Genet. 2002;3(9):717-24.

63. Postlethwait JH, Woods IG, Ngo-Hazelett, et al. Zebrafish comparative genomics and the origins of vertebratae chromosomes. Genome Res. 2000;10(12):1890-902.

64. Rink Edan Wulliman MF. Connections of the ventral telencephalon (subpallium) in the zebrafish (Danio rerio). Brain Res. 2004;1011(2):206-20.

65. Wulliman MF dan Muller T. Teleostean and mammalian forebrains contrasted: evidence from genes to behavior. J. Comp. Neurol. 2004;475(2):143-62.

66. Goldsmith P dan Fleming A. Screening methods employing zebrafish and the blood brain barrier. 2007.

67. Whitfield TT. Zebrafish as a model for hearing and deafness. J. Neurobiol. 2002;53(2):157-71. 
68. Renshaw SA dan Trede NS. A model 450 million years in the making: zebrafish and vertebrate immunity. Dis. Model Mech. 2012;5(1):38-47.

69. Phelps HA dan Neely MN. Evolution of the zebrafish model: from development to immunity and infectious disease. Zebrafish. 2005;2(2):87103.

70. Christoffersen TB, Kania PW, von Gersdorff Jorgensen L, Buchmann K. Zebrafish Danio rerio as a model to study the immune response against infection with Ichthyophthirius multifiliis. Journal of Fish Diseases. 2016:1-6.

71. Liu S dan Leach SD. Zebrafish models for cancer. Annual Review of Pathology: Mechanisms of Disease. 2011;6:71-93.

72. Shive HR. Zebrafish models for human cancer. Veterinary Patology. 2012;50(3):468-82.

73. Feitsma H dan Cuppen E. Zebrafish as a cancer model. Mol. Cancer. Res. 2008;6(5):685-94.

74. Mione MC dan Trede NS. The Zebrafish as a model for cancer. Disease Models and Mechanisms. 2010;3(9-10):517-23.

75. Mizgirev IV, Revskoy S. a new zebrafish model for experimental leukemia therapy. Cancer Biology and Therapy. 2010;9(11):1-9.

76. Tobia C, Gariano G, De Sena G, Presta M. Zebrafish embryo as a tool to study tumor/endothelial cell-cross talk. Biochimica et Biophysica Acta. 2013;1832(9):1371-7.

77. Choorapoikayil S, Overvoorde J, Den Hertog J. Deriving cell lines from zebrafish embryos and tumors. Zebrafish. 2013;10(3):316-25.

78. Zhang B, Shimada Y, Kuroyanagi J, Nishimura Y, Umemoto N, Nomoto T, Shintou T, Miyazaki T, Tanaka T. Zebrafish xenotransplantation model for cancer stem-like cell study and highthroughput screening inhibitors. Tumor Biol. 2014;35(12):11861-9.

79. Brown HK, Schiavone K, Tazzyman S, Heymann D, Chico TJA. Zebrafish xenograft models of cancer and metastasis for drug discovery. Expert Opinion on Drug Discovery. 2016;12(4):379-89.

80. Serbedzija GN, Flynn E, Willett CE. Zebrafish angiogenesis: a new model for drug screening. Angiogenesis. 1999;3(4):353-9.
81. Teng Y, Xie X, Walker S, White DT, Mumm JS, Cowell JK. Evaluating human cancer cell metastasis in zebrafish. BMC Cancer. 2013;13(1):1-12.

82. Chitramuthu BP. Modelling human disease and development in zebrafish. Human Genet. Embryol. 2013;3(1):1-3.

83. Plantie E, Migocka-Patrzalek M, Daczewska M, Jagla K. Model organisms in the fight against muscular dystrophy: lessons from Drosophila and Zebrafish. Molecules. 2015;20(4):6237-53.

84. Basset DI dan Currie PD. The zebrafish as a model for muscular dysthrophy and congenital myopathy. Human Molecular Genetics. 2003;12(2):265-70.

85. Patton EE dan Zon LI. The Art and design of genetic screens: zebrafish. Genetics. 2001;2(12):956-66.

86. Howe DG, Bradford YM, Eagle A, Fashena D, Frazer K, Kalita P, et al. The zebrafish model organism database: new support for human disease models, mutation details, gene expression phenotypes and searching. Nucleic Acid Research. 2017;45(D1):D758-68.

87. DrieverW,Solnica-krezel L, Schier AF, etal.Agenetic screen for mutations affecting embryogenesis in zebrafish. Development. 1996;123(1):37-46.

88. Chen JN, Haffter P, Odenthal J, et al. Mutations affecting the cardiovascular system and other internal organs in zebrafish. Development. 1996;123(1):293-302.

89. Xu X, Meiler SE, Zhong TP, et al. Cardiomyopathy in zebrafish due to mutation in an alternatively spliced exon of titin. Nature Genetics. 2002;30(2):205-9.

90. Granato M, van Eeden FJM, Schach U, et al. Genes controlling and mediating locomotion behavior of the zebrafish embryo and larva. Development. 1996;123(1):399-413.

91. Bassett DI, Bryson-Richardson RJ, Daggett DF, Gautier P, Keenan DG, Currie PD. Dystrophin is required for the formation of stable muscle attachments in the zebrafish embryo. Development. 2003;130(23):5851-60.

92. Jagadeeswaran P dan Liu YC. Developmental expression of thrombrin in zebrafish embryos: a novel model to study hemostasis. Blood Cells Mol. Dis. 1997;23(2):147-56.

93. Jagadeeswaran P dan Liu YC. A hemophilia model 
in zebrafish: analysis of hemostasis. Blood Cells Mol. Dis. 1997;23(1):52-7.

94. Pasqualetti S, Conqiu T, Banfi G, Mariotti M. Alendronate rescued osteoporotic phenotype in a model of glucocorticoid-induced osteoporosis in adultzebrafish scale. Int.J. Exp. Pat. 2015;96(1):1120.

95. Barrett R, Chappell C, Quick M, Fleming A. A rapid, high-content, in vivo model of glucocorticoid-induced osteoporosis. Biotechnol. J. 2006;1(6):651-5.

96. Goldsmith JR dan Jobin C. Think small: zebrafish as a model system of human pathology. Journal of Biomedicine and Biotechnology. 2012;1-12. 